\title{
Synthesis and Characterization of a Novel Peptide-Grafted Cs and Evaluation of Its Nanoparticles for the Oral Delivery of Insulin, in vitro, and in vivo Study [Retraction]
}

Barbari GR, Dorkoosh F, Amini M, et al. Synthesis and characterization of a novel peptide-grafted Cs and evaluation of its nanoparticles for the oral delivery of insulin, in vitro, and in vivo study. Int J Nanomed. 2018;13:5127-5138.

The Editor in Chief and Publisher of International Journal of Nanomedicine wish to retract the published article.

The journal was notified of the potential duplication of images in Figure 4 and Figure 5 of the published article. It was observed that Figure 5 was an inverted version of Figure 4. The authors were asked for an explanation but were unable to provide a satisfactory response or provide the original raw data for the images. It was determined the first author, Ghullam Reza Barbari, was solely responsible for preparing the images, however all the authors had approved of the final article for publication.

The Editor in Chief determined the results and findings of the article were no longer valid and advised a retraction was the only course of action.

The authors wish to apologise for this error.

Our decision-making was informed by our policy on publishing ethics and integrity and the COPE guidelines on retraction.

The retracted article will remain online to maintain the scholarly record, but it will be digitally watermarked on each page as "Retracted".

\section{Publish your work in this journal}

The International Journal of Nanomedicine is an international, peerreviewed journal focusing on the application of nanotechnology in diagnostics, therapeutics, and drug delivery systems throughout the biomedical field. This journal is indexed on PubMed Central, MedLine, CAS, SciSearch ${ }^{\mathbb{R}}$, Current Contents ${ }^{\mathbb{B}} /$ Clinical Medicine,
Journal Citation Reports/Science Edition, EMBase, Scopus and the Elsevier Bibliographic databases. The manuscript management system is completely online and includes a very quick and fair peer-review system, which is all easy to use. Visit http://www.dovepress.com/ testimonials.php to read real quotes from published authors. 